\title{
PENGARUH GAYA KEPEMIMPINAN DAN DISIPLIN \\ KERJA TERHADAP KINERJA PEGAWAI, DENGAN \\ MOTIVASI KERJA SEBAGAI VARIABEL INTERVENING (Studi Pada Dinas Pendidikan Kabupaten Tanah Datar )
}

\author{
Widya Futriani, Riri Mayliza \\ Sekolah Tinggi Ilmu Ekonomi "KBP" \\ ririmayliza@akbpstie.ac.id \\ futrianiwidya0505@gmail.com
}

\begin{abstract}
This research was conducted in order to determine the effect of leadership style and discipline to employee performance that is mediated by the motivation to work on Tanah Datar District Education Office. The instrument used in this study was a questionnaire consisting of a number of statements about leadership style, work discipline, employee performance and motivation. This study used a sample of incidental sampling, where the entire population is taken overall research officer working as many as 72 people. Data analysis techniques used in this study is a simple linear regression test multilevel linear regression. Simple linear regression test is used to determine the effect of leadership style on employee performance, the effect of labor discipline on employee performance, the effect of work motivation on employee performance, and for linear regression stratified namely the effect of leadership style on employee performance mediated by motivation and influence of labor discipline against employee performance mediated by work motivation. The results showed that the leadership style positive and significant impact on performance, discipline, positive and significant impact on performance, motivation positive and significant impact on the performance, leadership style positive and significant effect on performance mediated by motivation and discipline positive and significant impact on performance mediated by motivation. this research is exspectedto further research.
\end{abstract}

Keywords: leadership style, discipline, motivation, performance. 


\section{PENDAHULUAN}

\section{Latar Belakang Masalah}

Sumber daya manusia mempunyai peranan yang besar dalam suatu organisasi, terutama untuk mencapai tujuan organisasi. Keberhasilan dalam mencapai tujuan organisasi didukung sepenuhnya dari sikap dan perilaku pegawai, pegawai mempunyai peranan penting dalam membentuk dan mengelola organisasi dan memanfaatkan teknologi yang ada. Dalamkenyataannya, keberhasilan suatu organisasiditentukanolehkepemimpinanyangdikembangkanpadaorganisasi itu dan motivasi yang diberikan kepada semua anggota atau bawahannya untuk mencapai tujuan tersebut. Hal ini disebabkan karena setiap pemimpin dapat memberikan pengaruh terhadap bawahannya.

Pegawai merupakan asset utama organisasi dan mempunyai peran yang strategis didalam organisasi sebagai pemikir, perencana, dan pengendali aktivitas organisasi. Demi tercapainya tujuan organisasi, pegawai memerlukan motivasi untuk bekerja lebih rajin dan memiliki kinerja yang berkualitas dan kuantitas sehingga akan memberikan kontribusi positif bagi perkembangan organisasi. Selain itu, organisasi perlu memperhatikan berbagai faktor yang dapat mempengaruhi motivasi pegawai dalam meningkatkan disiplin kerja dan gaya kepemimpinan, yang kondusif guna mendorong terciptanya sikap dan tindakan yang professional dalam menyelesaikan pekerjaan sesuai dengan bidang dan tanggung jawabnya masing- masing pegawai. Pemimpin harus memastikan bahwa kinerja bawahan dihargai dengan sepantasnya, dan bukan sebaliknya mengacuhkan dan tidak memberikan ganjaran positif atas kinerja bawahan.

Rendahnya kinerja pegawai dan motivasi pegawai yang dihadapi merupakan permasalahan yang harusdi diskusikan. Motivasi dapat mempengaruhi seseorang atau memberikan dorongan kepada seseorang untuk melakukan sesuatu.

Pada SKPD Dinas Pendidikan Kab. Tanah Datar sebuah lembaga pemerintah tentunya memiliki Rencana Strategis terikat dengan tugas pokok dan fungsinya dibidang pendidikan. Rencana tersebutdibagi dalam bentuk Rencana Kerja yang berperan melakukan target kegiatan dan pencapaian awal tahun kegiatan yang bertujuanmembahas anggaran keuangan kegiatan dan kapan kegiatan diselenggarakan. Sesudah kegiatan terlaksana dilakukan setiap pegawai melakukan evaluasi kinerja organisasi dilakukan dalam bentuk rapat pengendalian yang dilakukan setiap bulan. Dalam pengendalian tersebut dilaporkan pencapaian kinerja masing-masing bidang meliputi Target Fisik dan Realisasi Keuangan dalam bentuk Presentase. Selisih yang terjadi di tuangkan dalam bentuk besaran deviasi. Sebagai alat ukur dari hasil RKO yang tercapai.

Pada Dinas Pendidikan Kab. Tanah Dataryang memiliki tugas pokok untuk melaksanakan penyiapan perumusan, kebijakan teknis, pembinaan, pengkoordinasian penyelenggaraan tugas secara terpadu, dan pelayanan administrasi lingkungan dinas, serta pelaksanaan urusan program, keuangan, dan umum dan kepegawaian. Dinas Pendidikan Kab. Tanah Datar dalam melaksanakan tugas pokok tersebut terdapat kendala-kendala dalam melaksanakan tugas pokok yaitu bisa terjadinya penurunan kinerja pegawai. tidak hanya dari hasil data daya serap keuangan, Pada hasil rekap kehadiran Dinas Pendidikan Kab.Tanah Datar juga menunjukkan mengalami penurunan yang dapat dibuktikan dari hasil presentase rekap kehadiran. Pada hasil rekap kehadiran tersebut disetiap bulannya melakukan evaluasi absensi kehadiran. Dari hasil rekap absensi 
kehadiran tersebut dapat diukur dimana kinerja pegawai mengalami penurunan atau peningkatan di setiap bulannya.

Penurunan tersebut bisa dikarenakan pelaksanaan absensi masih menggunakan sistem manual (dengan tanda tangan kehadiran) sehingga sering pegawai tidak melakukan absensi, bisa disebabkan karena lupa, maupun sengaja seperti pulang lebih awal, datang terlambat, tidak masuk tanpa izin dan lain sebagainya. Dimana absensi berpengaruh terhadap besar kecilnya Tunjangan Perbaikan Penghasilan yang akan diterima PNS setiap bulannya. Dan dari segi penyelesaian tugas yang diberikan tiap-tiap bidang berdasarkan surat yang masuk ke Dinas Pendidikan Kab. Tanah Datar pegawai mampu mengerjakan beberapa pekerjaan atau tugas yang akan mendekati waktunya, jika masih lama waktu penyerahan tugas tersebut maka pegawai bisa mengerjakan tugas-tugas yang akan mendekati waktu penyerahannya. Dalam kaitannya kinerja pegawai tentunya harus segera diperbaruhi agar para pegawai SKPD Dinas Pendidikan Kab. Tanah Datar dapat memberikan pelayanan yang prima kepada masyarakat secara lebih profesional. Penelitian ini dilakukan untuk mengetahui apakah gaya kepemimpinan dan disiplin kerja mempunyai pengaruh signifikan terhadap kinerja pegawai dan apakah motivasi berfungsi sebagai intervening dalam mempengaruhi gaya keemimpinan dan disiplin kerja pada kinerja pegawai dalam suatu organisasi pemerintahan. Tujuannya untuk mengetahui seberapa pengaruh gaya kepemimpinan dan disiplin kerja terhadap kinerja pegawai, untuk mengetahui pengaruh motivasi kerja sebagai variabel intervening dalam mempengaruhi gaya kepemimpinan dan disiplin kerja terhadap kinerja dan motivasi kerja terhadap kinerja pegawai

\section{LANDASAN TEORI \\ Kinerja Pegawai}

Kinerja pegawai menunjuk kemampuan pegawai dalam melaksanakan keseluruhan tugas-tugas yang menjadi tanggung jawabnya. Tugas tersebut biasanya berdasarkan indikator-indikator keberhasilan yang sudah diterapkan. Sebagai hasilnya akan diketahui bahwa seorang pegawai masuk dalam tingkatan kerja tertentu. Kinerja dapat dikelompokkan melampaui target, sesuai target atau dibawah target.Pengertian kinerja merupakan gambaran mengenai tingkat pencapaian pelaksanaan suatu program kegiatan atau kebijakan dalam mewujudkan sasaran, tujuan, visi, dan misi organisasi yang dituangkan melalui perencanaan strategis suatu organisasi (Moeheriono, 2010:60). Faktor yang mempengaruhi kinerja menurut Suprihatiningrum ( 2012:22) yaitu Motivasi, kepuasan kerja, tingkat stress, kondisi fisik pekerjaan, dan desain pekerjan.

\section{Motivasi Kerja}

Motivasi adalah seperangkat faktor yang dapat membangkitkan, mengarahkan dan memelihara perilaku seseorang untuk memilih jalan tertentu dalam mencapai tujuan (Sugiyono,2013:134). Manullang (2006:166) motivasi kerja adalah sesuatu yang menimbulkan dorongan dan semangat kerja. Seorang pemimpin harus memberikan perhatian kepada pegawai tentang pentingnya tujuan dari suatu pekerjaan agar timbul minat pegawai terhadap pelaksanaan kerja.Menurut(Ardana dkk, 2012:193) jenis motivasi dapat dibagi tiga yaitu: (1) Material incentive : pendorong yang dapat dinilai dengan uang,(2) Semi material incentive,(3) Non material incentive : yang tak dapat dinilai dengan uang 


\section{Teori Motivasi}

Teori motivasi menurut Maslow Maslow dalam Reksohadiprojo dan Handoko ( 1996 ) membagi kebutuhan manusia seperti kebutuhan fisiologis, kebutuhan rasa aman, kebutuhan sosial, penghargaan, dan aktualisasi diri

\section{Gaya Kepemimpinan}

Thoha (2001:49) menjelaskan bahwa gaya kepemimpinan merupakan norma perilaku yang digunakan seseorang pada saat orang tersebut mencoba mempengaruhi perilakuorang lain.

Perilaku tersebut biasa di pengaruhi oleh beberapa faktor seperti nilai- nilai, asumsi,persepsi, harapan, maupun sikap-sikap yang ada dalam diripemimpin. Berbagai penelitian tentang gaya kepemimpinan yang dilakukanpara ahli mendasarkan pada asumsi bahwa pola perilaku tertentu pemimpin dalam mempengaruhi bawahan ikut menentukan efektivitasnya dalam pemimpin.Gaya kepemimpinan adalah perilaku atau cara yang dipilih dan dipergunakan pemimpin dalam mempengaruhi pikiran, perasaan, sikap, dan perilaku para anggota organisasi atau bawahan. Hubungan pimpinan dan bawahan dapat diukur melalui penilaian pekerja terhadap gaya kepemimpinan para pemimpin dalam mengarahkan dan membina para bawahannya untuk melaksanakan pekerjaan. Jenis gaya kepemimpinan Gaya Kepemimpinan yang Otoriter,Gaya Pemimpin yang Demokratis, Gaya Kepemimpinan Kendali Bebas.

\section{DisiplinKerja}

Disiplin merupakan bentuk pelatihan yang menegakkan peraturan- peraturan perusahaan (Mathis dan Jackson, 2002:314). Menurut Handoko (2008:208) disiplin adalah kegiatan manajemen untuk menjalankan standar-standar organisasi. Ada dua tipe kegiatan pendisiplinan, yaitu preventif dan korektif.

Berdasarkan pada landasan teori dan kerangka pemikiran di atas, makahipotesis maka penelitian ini adalah :

$\mathrm{H}_{1}$ : Gaya kepemimpinan berpengaruh positif terhadap Kinerja Pegawai

$\mathrm{H}_{2}$ : Disiplin kerja berpengaruh positif terhadap Kinerja Pegawai

$\mathrm{H}_{3}$ : Motivasi kerja berpengaruh positif terhadap Kinerja Pegawai.

$\mathrm{H}_{4}$ : gaya kepemimpinan berpengaruh positif terhadap kinerja pegawai melalui motivasi kerja

$\mathrm{H}_{5}$ : Disiplin kerja berpengaruh positif terhadap kinerja pegawai melalui motivasi kerja

\section{METODE PENELITIAN}

Objek penelitian dilakukan pada Dinas Pendidikan Kabupaten Tanah Datar. Data diperoleh secara primer dan sekunder. Jenis Penelitianini termasuk dalam asosiatif kausal dengan menggunakan pendekatan kuantitatif Penelitian asosiatif kausal bertujuan untuk mengetahui pengaruh antara dua variabel atau lebih yang mempengaruhi dan dipengaruhi dari variabel-variabel yang akan diteliti. Pendekatan kuantitatif digunakan karena data yang digunakan untuk menganalisis pengaruh antar variabel dinyatakan dengan angka. Yang menjadi populasi adalah seluruh pegawai Dinas Pendidikan Kab.Tanah Datar yang berjumlah 72 orang dengan sampel yang diambil dalam penelitian ini sebesar 72 orang pegawai.Teknik pengambilan sampel menggunakan sampling insidental karena teknik penentuan sampel berdasarkan kebetulan. Dikarenakan di lingkungan pegawai Dinas 
Pendidikan kabupaten Tanah Datar tidak selalu keseluruhan hadir dikarenakan ada yang melakukan kegiatan diluar kantor.

\section{Variabel Penelitian}

Penelitianinimenggunakantigavariabelyaituvariabelindependen yaitu Gaya Kepemimpinan dan Disiplin Kerja $\left(\mathrm{X}_{1}\right.$ dan $\left.\mathrm{X}_{2}\right)$, variabel dependen yaitu Kinerja Pegawai (Y) dan variabel intervening yaitu Motivasi Kerja (M).

Variabel intervening ( variabel ) mediasi adalah faktor-faktor yang secara teoritis mempengaruhi fenomena yang diteliti tetapi tidak dapat diukur dan dimanipulasi (Sugiyono,2013:98).

\section{Metode Analisis}

Metode Analisis adalah suatu metode dengan serangkaian tindakan dan pemikiran yang disengaja untuk menelaah sesutu hal yang secara mendalam atau pun terinci terutama dalam mengkaji bagian-bagian dari suatu totalitas. Maksudnya untuk mengetahui ciri masing-masing bagian, hubungan satu sama lain, serta peranannya dalam totalitas yang dimaksud.

Dalam penelitian ini, analisis bertingkat digunakan untuk mengetahui hubungan sebab akibat,dengan tujuan menerangkan akibat langsung dan akibat tidak langsung seperangkat variabel, sebagai variabel penyebab terhadap variabel lainnya yang merupakan variabel akibat. Analisis bertingkat merupakan perluasan dari analisis regresi linear sederhana, atau analisis bertingkat adalah penggunaan analisis regresi untuk menaksir hubungan kausalitas antara variabel (model casual) yang telah ditetapkan sebelumnya berdasarkan teori (Ghozali, 2013:249).

Metode analisis data yang digunakan dalam penelitian ini adalah analisis regresi bertingkat karenapenelitianinginmemastikanapakahadapengaruh antara Gaya kepemimpinan (X1) dan Disiplin kerja (X2) terhadap Kinerja pegawai (Y) dengan Motivasi kerja (M) sebagai variabel Intervening. Berdasarkan tujuan dari penelitian ini, maka beberapa metode analisis data yang akan digunakan dalam penelitian ini adalah sebagai berikut:

\section{Uji Instrumen}

\section{Uji Validitas}

Uji validitas digunakan untuk mengukur sah atau valid tidaknya suatu kuesioner. Suatu kuesioner dikatakan valid jika pertanyaan pada kuesioner mampu untuk mengungkapkan sesuatu yang akan diukur oleh kuesioner tersebut (Ghozali, 2013:52). Metode yang digunakan untuk menguji validitas pada penelitian ini adalah menggunakan analisis faktor konfirmatori. Analisis faktor konfirmatori digunakan untuk menguji apakah suatu konstruk mempunyai unidimensionalitas atau apakah indikator-indikator yang digunakan dapat mengkonfirmasikan sebuah kontruk atau variabel (Ghozali, 2013:55). Jika hasilnya signifikan maka indikator pada masing-masing pertanyaan adalah valid. Pengujian validitas ini dibantu dengan program SPSS 22. Uji validitas dilakukan sebaiknya dilakukan secara terpisah pada lembar kerja yang berbeda antara konstruk variable dengan konstruk variable lainnya sehingga dapat diketahui butir-butir pertanyaan variable mana yang paling banyak tidak valid. Sehingga pengambilan keputusan adalah: (1).Jika Corrected Item-Total Correlation $>0,300$ maka dikatakan Valid. (2)Jika Corrected Item-Total Correlation $<0,300$ maka dikatakan Tidak Valid 


\section{Uji Reliabilitas}

Uji reliabilitas sebenarnya adalah alat untuk mengukur suatu kuesioner yang merupakan indikator dari variabel atau konstruk. Suatu kuesioner yang merupakanindikatordarivariabelataukonstruk. Suatu kuesioner dikatakan reliabel atau handal jika jawaban seseorang terhadap terhadap pernyataan adalah konsisten atau stabil dari waktu ke waktu (Ghozali, 2013:47). Uji reliabilitas dapat dilakukan dengan menggunakan bantuan program SPSS 22, memberikan fasilitas untuk mengukur reliabilitas dengan uji statistik Cronbach $\operatorname{Alpha}(\alpha)$.Suatukonstrukatauvariabeldikatakanreliabeljika memberikan nilai Cronbach Alpha > 0.60 (Nunnally dalam Ghozali, 2013:48).

\section{Analisis Deskriptif}

Untuk mengetahui rata-rata skor dari masing-masing butir pertanyaan di gunakan rumus sebagai berikut : (Arikunto, 2002)

$$
\frac{\text { Rata-rata Skor }=\mathrm{Fi} \text { x Wo }}{\mathrm{F}}
$$

Dimana :

$\mathrm{Fi}=$ Total Frekuensi ke i

$\mathrm{Wo}=$ Bobot

$\mathrm{F}=$ Total Frekuensi

Untuk mengetahui responden untuk mencapai nilai maksimal dari masingmasing variabel penelitian di gunakan dengan cara sebagai berikut : (arikunto;2002)

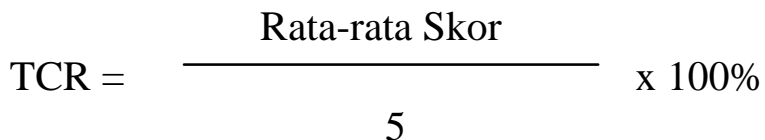

Sudjana;2002, mengemukakan kriteria jawaban responden untuk TCR adalah sebagai berukut:(1). jika TCR berkisar antara $0 \%$ sampai dengan $54,9 \%$ berarti tidak baik.(2)jika TCR berkisar antara 55\% sampai dengan 64,9\% berarti kurang baik.(3)jika TCR berkisar antara 65\% sampai dengan 79,9\% berarti cukup baik.(4)jika TCR berkisar antara $80 \%$ sampai dengan $89,9 \%$ berarti baik.(5)jika TCR berkisar antara $90 \%$ sampai dengan $100 \%$ berarti sangat baik

\section{Uji Asumsi Klasik}

\section{Uji Normalitas}

Uji normalitas bertujuan untuk menguji apakah dalam model regresi, variabelpenggangguatauresidualmemilikidistribusinormal.Sepertidiketahuibahwa uji t dan $\mathrm{F}$ mengasumsikan bahwa nilai residual mengikuti distribusi normal. Kalau asumsi ini dilanggar maka uji statistik menjadi tidak valid untukjumlah sampel kecil (Ghozali, 2013:160).

\section{Uji Multikolineartias}

Multikolinieritas dapat diketahui dengan melakukan analisis matrik korelasivariabel variabelindependen.Jikaantarvariabelindependenmemilikitingkatkorelasiyangcuk uptinggi,makamenunjukkanadanyamultikolinieritas (Ghozali, 2013:105).

\section{Uji Heteroskedastisitas}

Tujuan dilakukan uji heteroskedastisitas adalah untuk mengetahui apakah model regresi terjadi ketidaksamaan variance dari satu pengamatan ke pengamatan yang lain (Ghozali, 2013:139). Jika variance dari pengamatan yang ada tetap, maka disebut homokedastisitas, namun jika berbeda 
disebutheteroskedastisitas. Model regresi yang baik adalah data yang bersifat homokedastisitas atau tidak terjadi heteroskedastisitas.

\section{Analisis Regresi}

Analisis regresiadalah suatu analisis yang bertujuan untuk mengetahui pengaruh suatu variabel terhadap variabel lainnya. digunakan untuk mengetahuiada tidaknya pengaruh antara motivasi kerja terhadap gaya kepemimpinan, disiplin kerja dan implikasinya terhadap kinerja.

\section{Analisis Regresi Berganda}

Analisis regresi bergandaadalah suatu teknik statistik yang diginakan untuk mengetahui seberapa besar pengaruhbeberapa variable kerikat. Digunakan untuk mengetahui ada tidaknya pengaruh antara motivasi kerja terhadap gaya kepemimpinan, disiplin kerja dan implikasinya terhadap kinerja.

\section{Analisis Regresi Linear Sederhana}

Analisis regresi linear sederhana adalah suatu teknik statistik yang digunakan untuk mengetahui seberapa besar pengaruh variabel bebas terhadap variabel terikat, dimana tujuan menggunakan analisa regresi linear pada penelitian ini adalah untuk mengetahui pengaruh motivasi kerja terhadap kinerja pegawai.(1).Pengaruh motivasi kerja terhadap Kinerja Pegawai dengan persamaan sebagai berikut :

$$
\mathrm{Y}=\mathrm{a}+\beta \mathrm{M}+\mathrm{e}
$$

Dimana:

$$
\begin{aligned}
& Y=\text { Kinerja pegawai } \\
& a=\text { Konstanta } \\
& \beta=\text { Koefisien regresi } \\
& M=\text { Motivasi kerja } \\
& e=\text { Variabel yang mempengaruhi }
\end{aligned}
$$

\section{Analisa Regresi Linear Bertingkat}

Analisa regresi bertingkat ( hierarchical regression analysis ) Merupakan suatu teknik statistik yang digunakan untuk mengetahui pengaruh variabel perantara ( intervening variable) yaitu komitmen organisasi terhadap hubungan antara variabel bebas yaitu kepuasan kerja dengan variabel terikat yaitu turnover intention. (1). Pengaruh Gaya kepemimpinan dan disiplin kerja terhadap kinerja pegawai dengan persamaan sebagai berikut :Y= $\mathrm{a}+\beta 1 \mathrm{X} 1+\beta 2 \mathrm{X} 2+\mathrm{e}$. (2). Pengaruh Gaya kepemimpinan dan disiplin kerja terhadap kinerja pegawai melalui motivasi kerjaM $=\mathrm{a}+\beta 1 \mathrm{X} 1+\mathrm{B} 1 \mathrm{X} 2+\mathrm{e}$

\section{Uji Hipotesis}

\section{UJi T}

Menurut Imam Ghozali (2013:98) uji t pada dasarnya menunjukkan seberapa jauh pengaruh satu variabel penjelas/independen secara individual dalam menerangkan variasi variabel dependen. Hipotesis nol (Ho) yang hendak diuji adalah apakah suatu parameter (bi) sama dengan nol, atau :

$$
\text { Ho : bi }=0
$$

Artinya apakah suatu variabel independen bukan merupakan penjelas yang signifikan terhadap variabel dependen. Hipotesis alternatifnya (HA) parameter suatu variabel tidak sama denagan nol, atau : $\mathrm{HA} \neq 0$ : bi

Artinya variabel tersebut merupakan penjelas yang signifikan terhadap variabel dependen. Cara melakukan uji t adalah sebagai berikut (Ghozali, 2013:99): 
Quick look:bilajumlahdegree of freedom(df)adalah20ataulebihdan derajat kepercayaan sebesar 0,05 maka Ho yang menyatakan bi $=0$ dapat ditolak bila nilai t lebih besar dari 2 (dalam nilai absolut). Dengan kata lain kita menerima hipotesis alternatif yang menyatakan suatu variabel independen secara individual mempengaruhi variabel dependen.Membandingkan nilai statistik $\mathrm{t}$ dengan titik kritis menurut tabel. Apabila nilai statistik $\mathrm{t}$ hasil perhitungan lebih tinggi dibandingkan nilai tabel, kita menerima hipotesis alternatif variabel independen secara individual mempengaruhi variabel dependen.

\section{Analisis Koefisien Determinasi $\left(\mathbf{R}^{2}\right)$}

Koefisien determinasi $\left(\mathrm{R}^{2}\right)$ pada intinya mengukur seberapa jauh kemampuanmodel dalam menerangkan variasi variabel terikat (Ghozali, 2005). Nilai Koefisiendeterminasi adalah antara nol dan satu. Nilai $\mathrm{R}^{2}$ yang kecil berarti kemampuanvariabel-variabel bebas (gaya kepemimpinan, motivasi dan disiplin kerja) dalammenjelaskan variasi variabel dependent (kinerja pegawai) amat terbatas. Begitu pulasebaliknya, nilai yang mendekati satu berarti variabelvariabel bebas memberikanhampir semua informasi yang

dibutuhkan untuk memprediksi variasi variabel terikat.Kelemahan mendasar penggunaan koefisien determinasi adalah terhadapjumlah variabel bebas yang dimasukkan kedalam model. Setiap tambahan satuvariabel bebas, maka $\mathrm{R}^{2}$ pasti meningkat tidak perduli apakah variabel tersebutberpengaruh secara signifikan terhadap variabel terikat. Oleh karena itu, banyakpeneliti menganjurkan untuk menggunakan nilai Adjusted $\mathrm{R}^{2}$ pada saat mengevaluasimana model regresi yang terbaik. Tidak seperti $\mathrm{R}^{2}$, nilai Adjusted $\mathrm{R}^{2}$ dapat naik atauturun apabila satu variabel independen ditambahkan kedalam model.

\section{HASIL PENELITIAN DAN PEMBAHASAN \\ Analisa Regresi Linear Sederhana}

Hasil analisis regresi linear sederhana yang diolah dengan mengunakan SPSS, diringkas pada tabel 1:

Tabel 1

Hasil Pengujian Persamaan Regresi Linear Sederhana (M-Y)

\begin{tabular}{|c|c|c|c|c|c|c|}
\hline \multirow{2}{*}{ Mode } & & \multicolumn{2}{|c|}{ Unstandardized Coefficients } & \multirow{2}{*}{$\begin{array}{c}\text { Standardized Coefficients } \\
\text { Beta }\end{array}$} & \multirow[b]{2}{*}{$\mathrm{T}$} & \multirow[b]{2}{*}{ Sig. } \\
\hline & & $\mathrm{B}$ & Std. Error & & & \\
\hline \multirow[t]{2}{*}{1} & (Constant) & 3,477 & 2,768 & & 1,256 & ,214 \\
\hline & $\mathrm{X} 2$ &, 720 &, 113 & ,642 & 6,379 &, 000 \\
\hline \multirow[t]{3}{*}{2} & (Constant) & 3,247 & 2,760 & & 1,176 & ,244 \\
\hline & X2 & ,272 & ,373 & ,242 & ,729 & ,469 \\
\hline & $\mathrm{M}$ & ,548 & 433 & ,420 & 1,264 & 212 \\
\hline
\end{tabular}

Berdasarkan tabel maka ringkasan hasil pengujian dapat diformulasikan persamaan regresinya sebagai berikut : (1).Persamaan dapat ditulis sebagai berikut $: Y=3,723+0,849 \mathrm{M}$. (2). Variabel Motivasi kerja berpengaruh positif dan signifikan terhadap Kinerja Pegawai karena nilai signifikannya adalah 0,000 < 0,05 dan nilai koefisien regresinya adalah 0,849

\section{Analisis Regresi Linear Bertingkat}

Adapun tujuan melakukan analisis regresi bertingkat adalah untuk menguji pengaruh Motivasi Kerja sebagai variabel perantara ( intervening ) antara : (1). Gaya Kepmimpinan terhadap Kinerja Pegawai pada Dinas Pendidikan Kabupaten Tanah Datar. (2).Disiplin Kerja terhadap Kinerja Pegawai pada Dinas Pendidikan Kabupaten Tanah Datar. 
Tabel 2

Hasil Pengujian Persamaan Regresi LinearBertingkat (X1-Y-M)

\begin{tabular}{|c|c|c|c|c|c|}
\hline \multicolumn{6}{|c|}{ Coefficients $^{a}$} \\
\hline \multirow[b]{2}{*}{ Model } & \multicolumn{2}{|c|}{ Unstandardized Coefficients } & $\begin{array}{c}\text { Standardized } \\
\text { Coefficients }\end{array}$ & \multirow[b]{2}{*}{$\mathrm{t}$} & \multirow[b]{2}{*}{ Sig. } \\
\hline & $B$ & Std. Error & Beta & & \\
\hline (Constant) & 13,660 & 3,298 & & 4,141 &, 000 \\
\hline $\mathrm{X} 1$ & ,397 &, 176 & ,284 & 2,256 & ,028 \\
\hline (Constant) & $-1,097$ & 3,421 & &,- 321 & ,750 \\
\hline $\mathrm{X} 1$ & ,294 & ,136 & ,210 & 2,157 & ,035 \\
\hline$M$ & ,816 & ,127 & ,626 & 6,422 &, 000 \\
\hline
\end{tabular}

maka ringkasan hasil pengujian dapat diformulasikan persamaan regresinya sebagai berikut : (1). Tahap 1. Variabel Gaya kepemimipinan ( X1 ) berpengaruh positif dan signifikan terhadap Kinerja Pegawai ( Y ) dimana nilai Koefisien regresinya adalah 0,397 dan tingkat signifikan adalah lebih kecil 0,05 yaitu sebesar 0,028. (2). Tahap 2. Pada tahap ini Gaya kepemimpinan ( X1 ) terhadap Kinerja Pegawai ( Y ) melalui Motivasi Kerja ( M ) sebagai Variabel Intervening. Pengaruh variabel gaya kepemimpinan ( X1 ) berpengaruh signifikan terhadap Kinerja pegawai ( Y ) karena nilai signifikan lebih besar dari 0,05 yaitu sebesar 0,035 . Hal ini dapat diartikan bahwa Motivasi kerja ( M ) berperan sebagai variabel full intervening antara Gaya kepemimpinan dan kinerja pegawai.

Variabel Motivasi kerja ( M ) ditemukan berpengaruh signifikan terhadap kinerja pegawai ( $\mathrm{Y}$ ) karena nilai signifikannya adalah 0,000 atau $0,000<0,05$.

Berdasarkan tabel maka ringkasan hasil pengujian dapat diformulasikan persamaan regresinya sebagai berikut : (1). Tahap 1. Variabel Disiplin kerja (X2 ) berpengaruh positif dan signifikan terhadap Kinerja Pegawai ( Y ) dimana nilai Koefisien regresinya adalah 0,720 dan tingkat signifikan adalah lebih kecil 0,05 yaitu sebesar 0,000. (2). Tahap 2. Pada tahap ini Disiplin Kerja ( X2 ) terhadap Kinerja Pegawai ( Y ) melalui Motivasi Kerja ( M ) sebagai Variabel Intervening. Pengaruh variabel disiplin kerja ( X2 ) tidak berpengaruh signifikan terhadap Kinerja pegawai ( Y ) karena nilai signifikan lebih besar dari 0,05 yaitu sebesar 0,469 . Hal ini dapat diartikan bahwa Motivasi kerja ( M ) berperan sebagai variabel full intervening antara disiplin kerja dan kinerja pegawai.

Variabel Motivasi kerja ( M ) ditemukan tidak berpengaruh signifikan terhadap kinerja pegawai ( Y ) karena nilai signifikannya adalah 0,212 atau 0,212 $>0,05$.

\section{PEMBAHASAN}

Berdasarkan hasil pengujian secara statistik dapat terlihat dengan jelas bahwa secara parsial (individu) semua variabel bebas berpengaruh terhadap variabel terikat. Pengaruh yang diberikan kedua variabel bebas tersebut bersifat positif artinya semakin tinggi gaya kepemimpinan dan disiplin kerja maka semakin tinggi pula kinerja pegawai yang dihasilkan. Hasil tersebut sesuai dengan hipotesis yang diajukan. Hasil penelitian ini juga sesuai dengan hasil penelitian sebelumnya. Penjelasan dari masing-masing pengaruh variabel dijelaskan sebagai berikut: 


\section{Pengaruh Gaya Kepemimpinan terhadap Kinerja Pegawai}

Hasil pengujian hipotesis telah membuktikan terdapat pengaruh antara gaya kepemimpinan terhadap kinerja pegawai. Melalui hasil perhitungan yang telah dilakukan diperoleh nilai t hitung sebesar 2,423 dengan taraf signifikansi hasil sebesar 0,019 tersebut lebih kecil dari 0,05, dengan demikian Ha diterima dan Ho ditolak. Jadi gaya kepemimpinan berpengaruh positif terhadap kinerja pegawai. Luthans (2006:637) kepemimpinan adalah fokus dan saluran bagi sebagian besar area perilaku organisasi. Karena seseorang pemimpin adalah penggerak seluruhsumberdayayangadadiperusahaan. Penelitian terdahulu ditunjukan dengan hasil pengujian hipotesis berupa hubungan yang positif dan signifikan antara gaya kepemimpinan dan kinerja karyawan dengan koefisien korelasi sebesar 0,287.

\section{Pengaruh Disiplin Kerja terhadap Kinerja Pegawai}

Hasil pengujian hipotesis telah membuktikan terdapat pengaruh antara disiplin kerja terhadap Kinerja pegawai. Melalui hasil perhitungan yang telah dilakukan didapat nilai t hitung sebesar 6,431 dengan taraf signifikansi hitung sebesar 0,000 tersebut lebih kecil dari 0,05, yang berarti bahwa hipotesis dalam penelitian ini mengatakan bahwa Ha diterima dan Ho ditolak, jadi disiplin kerja berpengaruh positif terhadap kinerja pegawai. Fathoni (2006:126) mengungkapkan kedisiplinan dapat diartikan bila pegawai selalu datang dan pulang tepat pada waktunya, mematuhi semua peraturan perusahaan dan normanorma sosial yang berlaku.

\section{Pengaruh Motivasi terhadap Kinerja Pegawai}

Hasil pengujian hipotesis telah membuktikan terdapat pengaruh antara motivasi kerja terhadap kinerja pegawai. Melalui hasil perhitungan yang telah dilakukandiperoleh nilai t hitung sebesar 6,521 dengan taraf signifikansi hasil sebesar 0,000 tersebut lebih kecil dari 0,05, yang berarti bahwa hipotesis dalam penelitian ini bahwa Ha diterima dan Ho ditolak. Pengujian ini secara statistik membuktikan bahwa motivasi kerja berpengaruh positif terhadap kinerja pegawai. Artinya bahwa ada pengaruhantara variabel motivasi kerja terhadap kinerja pegawai di Dinas pendidikan Kab. Tanah datar. Ardana dkk (2012:193) menyatakan motivasi kerja adalah sesuatu yang menimbulkan dorongan atau semangat kerja atau pendorong semangat. Hal ini berarti bahwa setiap peningkatan motivasi kerja pegawai akan memberikan peningkatan yang sangat berarti bagi peningkatan kinerja pegawai dalam melaksanakan pekerjaannya. Penelitian Mahardhika (2013) menyimpulkan bahwa motivasi kerja berpengaruh positif terhadap kinerja. Semakin tinggi motivasi kerja maka akan semakin meningkatkan kinerja.

\section{Pengaruh Gaya kepemimpinan terhadap Kinerja Pegawai dengan motivasi kerja sebagai variabel intervening.}

Hasil pengujian hipotesis keempat, ditemukan bahwa variabel motivasi kerja berperan berperan sebagai full intervening antara gaya kepemimpinan dan kinerja pegawai. Full intervening terjadi apabila variabel bebas tidak berpengaruh signifikan terhadap variabel terikat setelah dikontrol oleh variabel mediasi. Hal ini dapat diketahui bahwa nilai signifikan kepuasan kerja terhadap kinerja pegawai setelah di mediasi oleh motivasi adalah 0,035 , nilai signifikan tersebut lebih besar dari $\alpha=0,05(0,035<0,05$; signifikan $)$.

Sementara itu diketahui bahwa besaran koefisien regresi variabel motivasi kerja adalah 0,816 dan signifikan sebesar 0,000. Nilai signifikan tersebut lebih kecil 
dari $\alpha=0,05(0,000<0,05)$. Hal ini dapat diartikan bahwa variabel motivasi kerja berfungsi sebagai variabel intervening antara gaya kepemimpinan terhadap kinerja pegawai pada Dinas Pendidikan Kab. Tanah Datar. Dengan demikian, hipotesis keempat ( $\mathrm{H}_{4}$ ) dalam penelitian ini yang menyatakan bahwa Motivasi kerja berfungsi sebagai intervening dalam mempengaruhi Gaya kepemimpinan terhadap kinerja pegawai pada Dinas Pendidikan Kab. Tanah Datar, dinyatakan di Terima.

Robbins dan Judge (2008:6) menyatakan kepemimpinan merupakan proses yang mencakup pemberian motivasi pegawai, pengaturan orang, pemilihan saluran komunikasi yang paling efektif, dan penyelesaian konflik. Menurut penelitian yang dilakukan (2013) gaya kepemimpinan mempunyai pengaruh yang positif dan signifikan terhadap motivasi kerja pada Dinas Tenaga Kerja Provinsi Lampung. Penelitian yang dilakukan menyatakan bahwa gaya kepemimpinan berpengaruh positif terhadap motivasi kerja. Semakin baik gaya kepemimpinan diterapkan dalam sebuah organisasi maka akan semakin meningkatkan motivasi kerja karyawannya.

\section{Pengaruh Disiplin Kerja terhadap Kinerja Pegawai dengan motivasi kerja sebagai variabel intervening.}

Hasil pengujian hipotesis kelima, ditemukan bahwa variabel motivasi kerja berperan berperan sebagai full intervening antara disiplin kerja dan kinerja pegawai. Full intervening terjadi apabila variabel bebas tidak berpengaruh signifikan terhadap variabel terikat setelah dikontrol oleh variabel mediasi. Hal ini dapat diketahui bahwa nilai signifikan disiplin kerja terhadap kinerja pegawai setelah di mediasi oleh motivasi kerja adalah 0,469 , nilai signifikan tersebut lebih besar dari $\alpha=0,05$ ( 0,469>0,05; tidak signifikan ).

Sementara itu diketahui bahwa besaran koefisien regresi variabel motivasi kerja adalah 0,548 dan signifikan sebesar 0,212. Nilai signifikan tersebut lebih besar dari $\alpha=0,05(0,212>0,05)$. Hal ini dapat diartikan bahwa variabel motivasi kerja berfungsi sebagai variabel intervening antara disiplin kerja terhadap kinerja pegawai pada Dinas Pendidikan Kabupaten Tanah Datar. Dengan demikian, hipotesis kelima ( $\mathrm{H}_{5}$ ) dalam penelitian ini yang menyatakan bahwa motivasi kerja berfungsi sebagai intervening dalam mempengaruhi disiplin kerja terhadap kinerja pegawai pada Dinas Pendidikan Kab. Tanah Datar, dinyatakan di Terima. Robbins (2006:214) motivasi merupakan proses yang berperan pada intensitas, arah, dan lamanya berlangsung upaya individu ke arah pencapaian sasaran. Menurut penelitian yang dilakukan Hidayah dan Pribadi (2011) disiplin kerja mempunyai pengaruh positif dan signifikan terhadap motivasi kerja di Dinas Kelautan dan Perikanan Kota Semarang

\section{Pengujian Hipotesis}

\section{Uji t (Uji signifikasi Pengaruh Parsial)}

Hipotesis dalam penelitian ini diuji kebenarannya dengan menggunakan uji parsial. Pengujian dilakukan dengan melihat taraf signifikansi (value), jika taraf signifikansi yang dihasilkan dari perhitungan di bawah 0,05 maka hipotesis diterima, sebaliknya jika taraf signifikansi hasil hitung lebih besar dari 0,05 maka hipotesis ditolak. 
Tabel 3

Hasil Uji T Secara Parsial

\begin{tabular}{|c|c|c|c|c|c|}
\hline Model & T - Hit & T- tabel & sig & Alpha & ket \\
\hline GAYA KEPEMIMPINAN & 2,423 & 2,002 &, 019 & 0,05 & signifikan \\
\hline DISIPLIN KERJA & 6,431 & 2,002 & 000 & 0,05 & signifikan \\
\hline MOTIVASI KERJA & 6,521 & 2,002 &, 000 & 0,05 & signifikan \\
\hline
\end{tabular}

Sumber: Data diolah SPSS statistic versi 22

Dari tabel dapat diketahui bahwa hasil penelitian nilai signifikan untuk variabel Gaya Kepemimpinan adalah $0,019<0.05$ dan variabel disiplin kerja adalah $0,000<0.05$. Hal ini berarti signifikan $\mathrm{t}$ lebih besar dari gaya kepemimipinan 2,423>0,05 dan disiplin kerja 6,431>0,05 yang menunjukkan ada pengaruh yang positif dan signifikan antara gaya kepemimpinan dan disiplin kerja dengan kinerja pegawai secara parsial. Jadi hipotesis diterima dan dapat disimpulkan bahwa gaya kepemimpinan dan disiplin kerja berpengaruh signifikan terhadap kinerja pegawai di Dinas Pendidikan Kab.Tanah Datar.

Pada tahapan pengujian hipotesis t-statistik untuk variabel motivasi diperoleh nilai signifikansi hasil pengolahan data adalah sebesar 0,000 tahapan pengolahan data dilakukan dengan menggunakan tingkat kesalahan sebesar 0,05. Dengan demikian terlihat bahwa nilai signifikan 0,000 lebih kecil dari nilai alpha 0,05 maka keputusanya adalah Ha diterima dan Ho ditolak sehingga dapat disimpulkan bahwa motivasi kerja berpengaruh signifikan terhadap kinerja pegawai.

\section{Uji Koefisien Determinasi (R2 )}

Koefisien determinasi merupakan besaran yang menunjukkan besarnya variasivariabel dependen yang dapat dijelaskan oleh variable independennya. Dengan katalain, koefisien determinasi ini digunakan untuk mengukur seberapa jauh variabelvariabelbebas dalam menerangkan variabel terikatnya. Nilai koefisien determinasiditentukan dengan nilai adjusted $R$ square sebagaimana dapat dilihat pada tabel 4

Tabel 4

Uji Koefisien Determinasi Gaya Kepemimipinan, Disiplin Kerja, Motivasi kerja terhadap Kinerja Pegawai

Model Summary

\begin{tabular}{|l|r|r|r|r|}
\hline Model & R & R Square & Adjusted R Square & Std. Error of the Estimate \\
\hline 1 &, $684^{\mathrm{a}}$ &, 467 &, 449 & 1,849 \\
\hline
\end{tabular}

Pada tabel diatas dapat diketahui bahwa koefisien determinasi(adjusted R2) yang diperoleh sebesar 0,449. Hal ini berarti $44 \%$ variasi variabel kinerja pegawai dapat dijelaskan oleh variabel gaya kepemimpinan, disiplin kerja dan motivasi kerja, sedangkan sisanya sebesar 56\% dipengaruhi oleh variabel lain yang tidakdiajukan dalam penelitian ini.

\section{SIMPULAN}

Berdasarkan hasil penelitian dengan menyebarkan kuesioner sebanyak 72 sampel dan hanya kembali sebanyak 60 sampel dari responden yang ada di Dinas Pendidikan Kabupaten Tanah Datar untuk melihat pengaruh gaya kepemimpina dan disiplin kerja terhadap kinerja pegawai dengan motivasi kerja sebagai variabel 
intervening pada Dinas Pendidikan Kabupaten Tanah Datar, dikemukakan kesimpulan sebagai berikut : (1). Dalam uji T untuk membuktikan diketahui nilai signifikan untuk variabel Gaya Kepemimpinan adalah $0,019<0.05$. Hal ini menunjukkan ada pengaruh yang positif dan signifikan antara gaya kepemimpinan dengan kinerja pegawai secara parsial. (2). Dalam uji $\mathrm{T}$ untuk membuktikan diketahui nilai signifikan untuk variabel disiplin kerja adalah $0,000<0.05$. Hal ini menunjukkan ada pengaruh yang positif dan signifikan antara disiplin kerja dengan kinerja pegawai secara parsial. (3). Dalam uji $\mathrm{T}$ untuk membuktikan diketahui nilai signifikan untuk variabel Motivasi kerja adalah 0,000 $<0,05$. Hal ini menunjukan ada pengaruh yang positif dan signifikan anatara motivasi kerja dengan kinerja pegawai secara parsial. (4). Dalam uji T untuk membuktikan diketahui nilai signifikan untuk variabel Gaya Kepemimpinan adalah 0,019<0,05 dan Motivasi Kerja $0,000<0,05$. Hal ini menunjukan ada pengaruh yang positif dan signifikan anatara Gaya Kepemimpinan dengan kinerja pegawai melalui motivasi kerja dengan kinerja pegawai secara parsial. (5). Dalam uji T untuk membuktikan diketahui nilai signifikan untuk variabel disiplin kerja adalah 0,000 $<0,05$ dan Moivasi Kerja 0,212 > 0,05. Hal ini menunjukan ada pengaruh yang positif dan signifikan anatara Disiplin Kerja dengan kinerja pegawai secara parsial yaitu Ha diterima dan Ho di tolak dan motivasi kerja dengan kinerja pegawai berpengaruh negatif yaitu Ho diterima dan Ha ditolak.

\section{DAFTAR PUSTAKA}

Abdurrahmat Fathoni. 2006.Manajemen Sumber Daya Manusia. Bandung : Rineka Cipta

Aldi, Y., \& Susanti, F. (2019). Pengaruh Stress Kerja Dan Motivasi Kerja Terhadap Prestasi Kerja Karyawan Pada PT. Frisian Flag Indonesia Wilayah Padang. https://doi.org/10.31227/osf.io/et4rn

Ardana, I Komang, Ni Wayan Mujiati, I Wayan Mudiartha Utama. 2012. Manajemen Sumber Daya Manusia. Edisi Pertama. Graha Ilmu.Yogyakarta.

Arikunto, Suharsimi. 2002. Prosedur Penelitian. Rineka Cipta. Yogyakarta

Bungin Burhan. 2004. Metode Penelitian Kualitatif.Penerbit:PTRajagrafindo Persada. Jakarta

Fendi, Z., \& Susanti, F. (2018). Pengaruh Kepuasan Kerja Terhadap Turnover Intention Dengan Komitmen Organisasi Sebagai Variabel Intervening Pada CV. Belibis Pariaman. https://doi.org/10.31227/osf.io/wumgx

Ghozali,Imam, 2013. Aplikasi Analisis Multivariat dengan Program IBM SPSS 21. Edisi7, Penerbit Universitas Diponegoro, Semarang.

Hani, Handoko T. 2008. Manajemen Personalia dan Sumber Daya Manusia.BPFE : Yogyakarta. 
Hasibuan. ( 2010). Manajemen Sumber Daya Manusia.Jakarta: Bumi Aksara.

Husein,Umar.2007. Metode Penelitian untuk skripsi dan tesis bisnis. Jakarta. PT.Raja Grafindo Persada.

Junaidi, R., \& Susanti, F. (2019). Pengaruh Gaya Kepemimpinan Dan Budaya Organisasi Terhadap Kinerja Pegawai Pada UPTD Baltekkomdik Dinas Pendidikan Provinsi Sumatera Barat. https://doi.org/10.31227/osf.io/bzq75

Kartini Kartono. 2008. Pemimpin dan Kepemimpinan. Jakarta: Raja Grafindo

Lubis, A. Y. O., \& Susanti, F. (2019). Pengaruh Gaya Kepemimpinan Dan Kompensasi Terhadap Prestasi Kerja Karyawan (Studi pada PT Japfa Comfeed Indonesia (JCI) Tbk Devisi Fam 1. https://doi.org/10.31227/osf.io/7tbrg

Luthans,fred. 2005. Perilaku Organisasi (organization behavior $10^{\text {th }}$ ).terj : Vivin Andhika Yuwono at all. edisi 10.Yogyakarta.ANDI

Luthans,Fred.2006. Perilaku Organisasi. Alih Bahasa V.A Yuwono. Yogyakarta:Andi

M, Manullang. 2006. Manajemen Personalia. Jakarta : PT. Ghalia Indonesia.

Mathis, dan Jackson. 2002.Manajemen Sumber Daya Manusia. Edisi pertama. Cetakan Pertama. Yogyakarta : Salemba Empat

Moeheriono.2010.Pengukuran Kinerja Berbasis Kompetensi.Surabaya:Galia indonesia.

Nurlaila. 2010. Manajemen Sumber Daya Manusia I. Ternate: Penerbit LepKhair

Regina Aditya. 2010. Pengaruh Gaya Kepemimpinan, Motivasi dan Disiplin kerja terhadap Kinerja karyawan PT. Sinar Sentosa Perkasa Banjar Negara

Ridho, M., \& Susanti, F. (2019). Pengaruh Stres Kerja Dan Motivasi Kerja Terhadap Kepuasan Kerja Pada Karyawan Bank Mandiri Syariah Cabang Padang. https://doi.org/10.31227/osf.io/pa2cg

Roscahyo, Agung. 2013. Pengaruh Gaya Kepemimpinan Terhadap Kinerja Karyawan pada Rumah Sakit Siti Khodijah. Surabaya.

Robbins SP dan Judge. 2002. Perilaku Organisasi buku 2. Jakarta : salemba empat

Safari. 2003. Evaluasi Pembelajaran. Departemen Pendidikan Nasional Direktorat Jendral Pendidikan Dasar dan Menengah Direktorat Tenaga Kependidikan 2003. 
Simamora, Henry. 2006. Manajemen Sumber Daya Manusia, Edisi 2, STIE YKPN.Yogyakarta

Sugiyono. 2013. Metode Penelitian Pendidikan Pendekatan Kuantitatif, Kualitatif dan $R \& D$. Bandung. ALFABETA

Suprihatiningrum, H dan Tri, B.2012.Faktor-faktor yang MempengaruhiPrestasi Kerja.Jurnal Manajemen

Susanto, R. (2018). Pengawasan Dan Lingkungan Kerja Terhadap Kinerja Karyawan PT. Bussan Auto Finance. https://doi.org/10.31227/osf.io/m3kge

Thoha,Miftah.2001.Perilaku Organisasi. Konsep Dasar dan Aplikasinya. Raja Grafindo Persada. Jakarta.

Triantoro, Safaria. 2004. "Kepemimpinan”. Edisi Pertama. Graha Ilmu. Yogyakarta.

Wibowo.2010. Manajemen Kinerja.Edisi Ketiga. Penerbit Rajawali Pers. Jakarta

Winardi. 2000. Manajer dan Manajemen. Bandung: Citra Aditya Bakti. Yudistira, D. S., \& Susanti, F. (2019). Pengaruh Motivasi Kerja Dan Budaya Kerja Terhadap Kinerja Karyawan Dinas Pemberdayaan Masyarakat Dan Desa, Pengendalian Penduduk Dan Keluarga Berencana Kabupaten Pesisir Selatan. https://doi.org/10.31227/osf.io/jk54m 